\title{
Marie-Helen Maras:
}

\section{A TERRORIZMUS ELMÉLETE ÉS GYAKORLATA ${ }^{1}$}

\author{
Betekintés korunk legnagyobb civilizációs fenyegetésének \\ strukturált felépítése mögé
}

Marie-Helen Maras: The CRC Press Terrorism Reader címü 2014-ben kiadott müvének 2016-ban megjelent magyar fordítása alapján

Az egyedülállóan széleskörü tudásanyagot feldolgozó, „A terrorizmus elmélete és gyakorlata" címü, aktualitását tekintve sajnálatos módon releváns szakkönyv oldalain Marie-Helen Maras az olykor még a hétköznapjainkat is beárnyékoló terrorizmus miértjeire segít választ keresni és találni. Kötete a terrorizmus különbözö aspektusait leíró fejezetek füzére, gondolatai mégis koherens egésszé kapcsolódnak össze, közelebb hozva az olvasóhoz a terrorizmus, illetve a terrorelhárítás fontos kérdéseit és problémáit.

A közel 550 oldalas mü öt különálló részre tagolódik: terrorizmus és a terrorizmus történelmi háttere, terrorista taktikák és képességek, a terrorizmusra adott válasz és felkészültség, terrorizmus regionális aspektusból és felmerülő kérdések, a terrorizmus jövője. A szerző célja a terrorizmus jelenségének széleskörü, minden releváns szemszögből megvilágított bemutatása. Marie-Helen Maras a biztonsági tanulmányok és a büntetőjog egyetemi docense a New York-i Városi Egyetemen ${ }^{2}$. A szerző a tanításon és a tudományos munkán kívül közel hét évet szolgált az Egyesült Âllamok haditengerészeténél, ahol jelentős tapasztalatra tett szert a biztonság és rendvédelem területén, mint a haditengerészet bűnügyi szakértője és fővizsgálója. A haditengerészetnél irányító szerepet töltött be, több mint 130 éles elhárító akcióban [p. 26].

„A terrorizmusról számos meghatározás forog a köztudatban (...). Ha van ezekben egyetlen közös motívum, akkor az az, hogy a terrorista akciók kiszámított cselekmények, azokat nem véletlenszerüen hajtják végre." [p. 44]. Az 1979-es évektől kezdődő és napjainkig tartó terrorcselekmények trendjét David Rapoport, a politikai erőszak kérdésének egyik legnagyobb szaktekintélye, a negyedik hullámként nevezi meg, mely négyes tagolás megközelítőleg kapcsolható a különböző korok terrorista közegeinek generációs változásaihoz és irányadó politikai ideológiáihoz. Ezen tagolás legfiatalabb generációjának kiemelkedő alakjai az al-Kaida harcosai, kiknek karizmatikus vallási és politikai vezetője Oszama bin Laden, aki retorikájában a megfélemlítés mellett már az uszítást is előtérbe helyezi, mely jelenség korábban kevésbé, vagy alig volt megfigyelhető

1 DOI: $10.14267 /$ RETP2018.02.24

2 Department of Security, Fire, and Emergency Management, John Jay College of Criminal Justice 
terroristák részéről. Fontos megjegyezni, hogy a korábban említett négyes tagoltságú osztályozási kategóriák kezdeti szakaszaiban a terrorizmus jellege kifejezetten világi és lokális volt, csak az ún. harmadik hullám, mely alatt főként a Palesztinai Felszabadítási Szervezetet (PSZF) értjük csatolta hozzá az iszlám fundamentalizmus jellemző jegyeit, melyet napjainkban sokan tévesen azonosítanak a terrorizmussal. Ennek oka többek között az lehet, hogy az utóbbi idők nyugat ellen intézett legnagyobb terrortámadásaként ismert 9/11-es merénylet „a globális iszlám ügyéért történt, nem pedig helyi nacionalista mozgalmak közvetlen követelése miatt”. [p. 397].

Ahogy Maras kiemeli, a jelenség, az újjáéledő iszlám világoffenzíva korunkban olyan fenyegetéssé nőtte ki magát, hogy az egyszeri izolált intézkedések már nem alkalmasak annak feltartóztatására, ugyanis, ahogy fogalmaz: „Az elmúlt évtizedek folyamán a terrorizmus egyre halálosabb természetűvé vált, mivel határokon átnyúló szervezetek a nemzetközi kommunikációs és szállítási hálózatokat használják, hogy az egész földön halált és pusztítást okozzanak." [p. 45]

\section{„AKI AZ EGYIK OLDALON TERRORISTA, AZ A MÁSIK OLDALON SZABADSÁGHARCOS." -RONALD REAGAN-}

Brian Jenkins, aki többek között biztonsági tanácsadója volt az Egyesült Államok védelmi minisztériumának, a Pentagonnak, a következőképpen definiálta a terrorizmus fogalmát: „Az erőszak kiszámított alkalmazása bizonyos politikai, vallási vagy ideológiai célok elérése érdekében.” Az erőszak ezen megnyilvánulásait a világpolitikai stabilitást fenyegető veszélynek kell tekinteni, hiszen a globális szintű, kölcsönös egymásrautaltság növekedésének dacára káosszal fenyeget. A globalizálódó gazdaság színterén kevesebb szerepet kapó, nyugati világon túli régiók megkérdőjelezik a szabályok érvényességét. Társadalmi elszigeteltségük, és a javaktól való megfosztottságuk következtében bizonyos esetekben igyekeznek a fennálló rend módosítására. Oszama Bin Laden szerint: „A világ igazságtalansága elért egy olyan pontot, ahol a békés módszerek már semmit sem érnek." A társadalmi igazságtalanság érzete szorongást vált ki belőlük és az ebből fakadó agressziójuk a terrorizmus keretei között kerül megélésre, tetteiket az életben maradás kényszerével igazolják, akcióik többsége nem kétségbeesés, hanem harc szülte megmozdulások.

A kötet górcső alá veszi a közel-keleti átrendeződés során kialakuló konfliktusokat, valamint az arab társadalmak gazdasági és szociális problémáit, amik forradalmakon keresztül a politikai viszonyok meggyengüléséhez vezettek. A hatalmi ür konfliktussorozatokhoz vezet, nemzeti hatáskörü kormányok hiányának hatására pedig törvénynélküliség és extremista csoportok tünnek föl, és az összeomlott állam területe a terrorizmus támaszpontjává válhat. Az átfogó hatalom hiányának hatására az infrastruktúra kielégítő mértékü kiépülése, valamint a színvonalas oktatás sem valósul meg (az analfabetizmus még mindig hatalmas arányban jelen van), amely következtében ezek a közel-keleti országok a globalizálódó világ peremére kerülnek. Ezen országok lakói így hát fiatal koruktól megtapasztalják az elégtelen életfeltételeknek köszönhető tehetetlenséget és megalázást, ami frusztrációt és elkeseredést szül, ez a globalizáció elleni gyülölethez, és végül terrorhoz vezethet, ami a reményvesztett emberek szemében a megváltás, a 
csoportos megaláztatásért való megtorlás, a bosszú, vagy a becsület visszaszerzésének eszközeként sejlik fel.

A konfliktus így hát önmagát generálva vallási jellegűvé és geopolitikai hatásúvá válik. A vallásból fegyvert kovácsolnak geopolitikai céljaik eléréséhez, a kommunikáció érdekében erőszakot celebrálnak, a nacionalista és vallási küzdelem legitimációjától áthatva civileket minősítenek legyilkolandónak, mely többnyire szimbolikus értékü - agresszióik a közvetlen áldozatoknál nagyobb célpont ellen irányulnak, általuk szélesebb közönséghez akarnak üzenetet eljuttatni. Módszereik kegyetlenségét az magyarázza, hogy újra definiálják az emberi élet kioltását érintő moralitást úgy, hogy azt nemcsak, hogy kínzó lelkiismeretfurdalás nélkül el lehessen követni, de még a büszkeség és hősiesség motívumait is hozzácsatolják. Céljuk rombolni a biztonságérzetet, töréseket, belső viszályt kiváltani a társadalomban, és „nullára leszúkíteni azokat a területeket, ahol az ember szabadon mer mozogni”. [p. 396].

\section{TERRORIZMUS A GYAKORLATBAN}

A kötet a következő fejezetekben a terrorizmus központjában lévő akciót elemzi több elméleti modell segítségével, melyek közül az ötfázisú terrortámadási ciklus e recenzióban is szerepel. Maras állítja, hogy a modern terrorizmus főbb megjelenési formái változnak: a hangsúly a sejtalapú operatív csoportokról nagyrészt az egyszemélyes merénylőkre, „magányos farkasokra” helyeződik át. Azonban ez nem változtat a terrortámadások szisztematikus felépítésén, melyet a szakértők öt elkülöníthető fázisban határoznak meg. A fent említett ún. ötfázisú terrortámadási ciklus a következőképpen tagolható: az első fázisban a csoport médiaérdeklődés és kivitelezhetőség alapján kiválasztja a cselekmény célpontját; a második fázis az anyaggyüjtésről, operatív tervezésről szól, mely gyakran a leghosszabb része egy támadásnak (és a terrorelhárítás megelözési szándéka is itt kap szerepet); a harmadik fázis maga a terrorcselekmény megvalósítása, a terv kivitelezése; a negyedik szakaszban - a terv sikerétől függetlenül - a sejt aktív végrehajtó tagjai elrejtőznek, menedékbe vonulnak (nyilvánvalóan az állítás nem igaz az elmúlt években növekvő tendenciát mutató öngyilkos robbantások esetében, amikor az elkövető egyértelműen nem tervez a túlélés lehetőségével); és a terrortámadási ciklus utolsó fázisában a csoport a médianyilvánosságot „hasznosítja”, nyilvánosan felelősséget vállal a cselekményért, ezzel az általa képviselt ügy(ek)re próbálja irányítani a figyelmet - ezen médiaorientált hadviselés célja, hogy az üzenet minél nagyobb tömegekhez érjen el.

Korábban, még az ezredforduló előtt, a szakértők között egyetértés mutatkozott abban, hogy a terrortámadások figyelemfelkeltő hatásának érdekében az elkövetők konzekvensen elkerülik a „túlzott” mértékü haláleseteket eredményező akciókat, ezek ugyanis egységesítenék a közvéleményt, mely a csoporttal együtt az általuk képviselt ügyet is széleskörüen elítélné. A támadásokra addig szimbolikus értékű agressziókként tekintettek. Azonban a 9/11-es támadásokat követően a nézet természetesen semmissé vált. Így valóssá válik annak a fenyegetése, hogy a terrorizmussal vádolt szélsőséges csoportok eszközei közé különböző nukleáris vagy biológiai fegyverek kerüljenek. Mára ez azt eredményezte, hogy nemzeteken átívelő kutatóközpontok elemzik a terrorista cso- 
portok, elsősorban az al-Kaida képességeit tömegpusztító fegyverek (WMD) bevethetőségének szempontjából.

A szerző ezen aggályok tekintetében pozitívan nyilatkozik, ugyanis véleménye szerint ezen WMD fegyverek beszerzésének kísérlete kapcsán egyértelmü és természetes nehézségekkel szembesülnek a terrorista csoportok, ugyanis a nukleáris fegyverek vagy alapanyagok nemcsak olyan konzisztens védelem alatt állnak, melynek feltörése meghaladja a csoportok képességeit, hanem ezen túlmenően nagyon komoly szakmai háttér is szükségeltetik bárminemü alkalmazásukhoz, amivel feltételezhetően a szervezetek nem rendelkeznek. Érdemes megemlíteni, hogy a terrorista motivációk másik eszköze a biológiai fegyverek alkalmazása, mely esetén ugyan a fentebb ismertetett nehézségek szintén fennállnak, ám mégis kimutathatóan erős vonzalom köti a merénylőket ezekhez a módszerekhez, kiváltképp azért, mert a fegyverek lélektani, egészségügyi és gazdasági hatásai leginkább a bibliai csapásokat idézik.

\section{VÁLASZ A TERRORIZMUSRA: BELBIZTONSÁG}

Már a '90-es években is komoly terrorista támadások érték az Egyesült Államokat, azonban a 2001. szeptember 11-én bekövetkezett katasztrófa mindenkit megdöbbentett és félelemmel töltött el. Ennek következtében a hidegháború óta a legnagyobb kormányátszervezés keretei között létrehoztak több belbiztonsági ügynökséget és tanácsot, köztük a Belbiztonsági Minisztériumot (DHS), mely a maga 180 ezer fös személyzetével 2003 márciusában kezdte meg a müködését. A szervezeti átalakítások mellett pedig további törvényi szigorítások következtek - a lakosság többségének egyetértésével -, melyek azonban a biztonság érdekében szignifikáns mértékben erodálták az állampolgárok szabadságát a korábbiakhoz képest. Ekkor kapott felhatalmazást a Nemzetbiztonsági Ügynökség (NSA) - a hagyományos szabadságjogokat sértő és ez alapján oly sokat támadott tevékenységére, miszerint, hogy beleegyezés nélkül hallgathassa le a civil lakosság bárminemü kommunikációs eszközét.

A szerző a kimerítő, az egész amerikai kontinenst érintő elemzését követően átfordítja figyelmét Európára, azon belül is kiemelten foglalkozik Németországgal. Azonban Németország nemzetbiztonsági struktúrájának az elemzése és kritikája bizonyos tekintetben az Európai Unió többi tagországára is érvényes, ugyanis elsősorban az ország lehetőségeit és korlátait vizsgálja a schengeni egyezmények tükrében. Így ismerteti a belbiztonsági feladatok és kérdések különböző attribútumait a tagállamok és az Unió közti felelősség- és hatáskörmegosztás szempontjából. Megállapítja, hogy Németország komoly hátránya, hogy egyértelmü bizalmatlanság tapasztalható egy teljeskörű belbiztonsági szerv létrejöttével kapcsolatban, melyet megalapozottan a világháborúk következményeként interpretál. Pozitívumként emeli ki, hogy a Berlinben 2004 decembere óta működő Egyesült Terrorvédelmi Központ (GTAZ) lehetővé tette a könnyebb információáramlást a különböző ügynökségek és biztonsági szervek között, mely szakítást jelent a korábbi fundamentalista munkamegosztás elveivel. Végeredményben pozitívnak értékeli a Németországban 9/11-et követő belbiztonsági folyamatok irányát és az ezekhez kapcsolódó határozatokat, bár véleménye szerint „magas árat kell fizetniük (az 
Uniós tagországok lakosságának) azért a szabadságért, hogy útlevél és ellenőrzés nélkül léphetik át a határokat." [p. 324].

A szerző a terrorizmus jövőjét taglaló fejezetekben foglalkozik az arab tavasszal és annak utóhatásaival, illetve az egész régió átalakulásának folyamatait is elemzi ország szerinti lebontásban, és ezekhez kapcsoltan különböző prognózisokat állít fel, ugyanis jelenleg biztonsággal egyik vízió bekövetkezése sem jósolható véleménye szerint. Külön fejezetet szentel a terrorizmus „csúcsfegyverének” számító öngyilkos merényletek pszichológiai és szervezeti hátterének tisztázására. A mü végén pedig az informatikai eszközökben és hálózatokban lévő potenciált részletezi, illetve az ezeken alapuló térinformatikai hírszerzés és emberföldrajz fontosságára hívja fel a figyelmet.

Maras-nak a témát teljes egészében átfogó és bemutató kötetével egy olyan hiánypótló, enciklopédikus igényességű alkotás válik elérhetővé a magyar olvasóközönség számára az Antall József Tudásközpont közremüködésével, mely olvasmányos, gondolati megközelítésével és a szakzsargon pontos alkalmazásával vitathatatlanul korszakalkotó a magyar nyelvü, terrorizmussal foglalkozó könyvek piacán.

Biro Marcell ${ }^{3}$ Tajti Alexandra ${ }^{4}$ 